\title{
Assessing site form as an indicator of site quality in even-aged Pinus radiata D. Don stands in north-western Spain
}

\author{
Juan Alberto Molina-Valero ${ }^{1}$ (D) - Ulises Diéguez-Aranda ${ }^{1}$ - Juan Gabriel Álvarez-González ${ }^{1}$. \\ Fernando Castedo-Dorado ${ }^{2}$. César Pérez-Cruzado ${ }^{1}$
}

Received: 29 March 2019 / Accepted: 18 November 2019 / Published online: 11 December 2019

(C) The Author(s) 2019

\begin{abstract}
- Key message Site form and site index have shown similar precision for estimating site quality in even-aged Pinus radiata D. Don stands in north-western Spain. Additionally, SF presents the advantage that it does not require stand age information and can therefore be used in a wider set of situations in the forestry practice.

- Context Estimation of site quality is essential for characterizing, monitoring and predicting forest resources. Site index (i.e. the dominant height of the stand at a reference age) is ordinarily used to estimate site quality; however, this index is only useful for even-aged stands of known age. By contrast, SF is age-independent as it uses the dominant height of the stand at a reference dominant diameter.

- Aims The aim of this study was to compare the performance of SF and SI for site quality estimation in even-aged $P$. radiata stands.

- Methods Dynamic equations derived with the Generalized Algebraic Difference Approach (GADA) from the Hossfeld IV base model were fitted to predict site quality with both SI and SF. SF predictions were compared with SI regarding variability within the same plot and consistency in site quality predictions, using the observed maximum mean annual volume increment (MAI) as a direct measure of site quality.
\end{abstract}

Contribution of the co-authors

Conceptualization: CPC JGAG; Methodology: CPC' JGAG, JAMV;

Formal Analysis: JAMV, UDA, CPC; Data curation: FCD; Writing - original draft: JAMV; Writing — review \& editing: JAMV, UDA, JGAG, FCD, CPC; Supervision: CPC, JGAG; Funding acquisition: CPC, FCD, JGAG, UDA.

Handling Editor: David Drew

This article is partof the topical collection on Frontiers in Modelling Future Forest Growth,Yield and Wood Properties

César Pérez-Cruzado

cesar.cruzado@usc.es

Juan Alberto Molina-Valero

juanalberto.molina.valero@usc.es

Ulises Diéguez-Aranda

ulises.dieguez@usc.es

Juan Gabriel Álvarez-González

juangabriel.alvarez@usc.es
Fernando Castedo-Dorado fccasd@unilean.es

1 Unidad de Gestión Ambiental y Forestal Sostenible (UXAFORES), Departamento de Ingeniería Agroforestal, Escuela Politécnica Superior de Ingeniería, Universidade de Santiago de Compostela, Benigno Ledo s/n, Campus Terra, 27002 Lugo, Spain

2 Departamento de Ingeniería y Ciencias Agrarias, Escuela Superior y Técnica de Ingeniería Agraria, Universidad de León, Avda. Astorga s/n, Campus de Ponferrada, 24401 Ponferrada, Spain 
- Results Both approaches showed good performance in model fitting and provided similar goodness-of-fit statistics and variability in the predictions. However, SI performed slightly stronger when related to MAI.

- Conclusion

- SF performed adequately in estimating site quality for even-aged P. radiata stands, with results comparable to those obtained using traditional SI.

Keywords Site index $\cdot$ Predicting $\cdot$ Dominant diameter $\cdot$ Dominant height $\cdot$ Stand age

\section{Introduction}

Assessing and monitoring forest resources require a reliable and efficient estimation of site quality, which is essential for predicting growth and yield of plant biomass under different management regimes for both even-aged (Skovsgaard and Vanclay 2008) and unevenaged stands (Peng 2000). Site quality is also important in studies concerning forest disturbances (Wei et al. 2003), forest structure (Larson et al. 2008) and ecological diversity (Franklin et al. 1989), among others. Site quality may be defined as the physical and biological factors that characterize a site's ability to support tree growth (Skovsgaard and Vanclay 2008). According to Vanclay and Henry (1988) and Weiskittel et al. (2011, p. 38), a site quality index should possess certain characteristics: (i) reproducible and consistent over long periods of time, (ii) indicative of the site, independent of management and/or stands conditions, (iii) correlated with the productive potential of the site as a causeeffect relationship, in line with the current knowledge of tree physiology (e.g. Coops et al. 1998), and (iv) at least as well as other site quality estimators. Regarding this last characteristic, even lesser precise site quality estimators are occasionally interesting, as long as they are based on widely available sources of information and therefore can reliably be applied at larger scales.

Site index (SI), defined as the average height of the dominant trees of the stand at a given reference age, is one of the most commonly used indicator of site quality for even-aged stands (Weiskittel et al. 2011, p. 38). It stems from the fact that height growth is highly correlated with stand volume productivity, and dominant height is not greatly affected by stand density or thinning treatments (assuming thinning from below) (Burkhart Harold and Tomé 2012, p. 131). Nevertheless, site index has several drawbacks: (i) Its use is questionable for uneven-aged stands because of the initial suppression of advanced regeneration, especially for shade tolerant species, and also because SI is an age-dependent approach, and age has nebulous meaning in the context of uneven-aged forests (Burkhart Harold and Tomé 2012, p. 339); (ii) identifying tree ages is a costly task; and (iii) stand age is often not known/available or with dubious reliability, e.g. in National Forest Inventories (Tomppo et al. 2010), which limits the use of SI for large-scale monitoring purposes. Although age-independent methods have been developed to overcome the latter problem, thus enabling modelling of the dominant height growth and estimation of site index in the absence of age data (e.g. Arias-Rodil et al. 2015), the reliability of these methods has not been widely tested. Because of this, it will be desirable to assess more age-independent methods, as this work aims.

Site form (SF), defined as the dominant height of the stand at a reference dominant diameter (Vanclay and Henry 1988), is an alternative for estimating site quality for different stand structures (even- and uneven-aged) because it does not require stand age information. Trorey (1932) first reported the use of the heightdiameter relationship as a site quality estimator. However, it was not until 1957 that McLintock and Darby (1957) proposed a site quality index based on Meyer's mathematical expression (Meyer 1940). The method was further established by Stout and Shumway (1982) and Reinhardt (1982). The term 'site form' was proposed to distinguish it from 'site index' in Vanclay (1983), and subsequently other researchers used SF in different studies in the 1980s and 1990s (Reinhardt 1983; Lamson 1987; Nicholas and Zedaker 1992; Vanclay 1992, 1994, 1995). However, reports of its use have been scarce in scientific literature in the last two decades (Adeyemi 2016; Ahmadi et al. 2017; Moreno-Fernández et al. 2018).

Some studies have analysed the relationship between SI and SF for a given species and between these indices and variables traditionally used as measures of site quality (Huang and Titus 1993; Wang 1998; Buda and Wang 2006; Beltran et al. 2016; Duan et al. 2018; Fu et al. 2018). However, only Wang (1998) and Beltran et al. (2016) considered species growing in even-aged stands. It must also be noted that the comparative performance of SI and SF can only be properly carried out in even-aged stands because SI, as was previously defined, has no significance in uneven-aged stands.

The overall aim of the present study was to compare the performance of SF and SI as indicators of site quality in evenaged Pinus radiata D. Don stands in north-western Spain. This species was selected for its importance in terms of both surface coverage and growing stock in the region, after Eucalyptus globulus Labill., Pinus pinaster Ait. and Quercus robur L. according to the last Spanish National Forest 
Inventory (IFN4) (Xunta de Galicia 2015); and because of the availability of permanent plot data covering the existing range of ages, site qualities, and stand densities within the study area, which have been measured up to five times (CastedoDorado et al. 2007). The overall aim was broken down into the following specific objectives: (i) to develop dynamic equations for estimating SI and SF, (ii) to compare the correlation between SI and SF predictions at plot level, (iii) to analyse the consistency of both indices when applied to data from remeasurements of the same plot, and (iv) to evaluate the correlation between both indices and a direct measure of site quality.

\section{Material and methods}

\subsection{Data}

The database used corresponds to a network of 158 permanent plots established by the Sustainable Forest Management Unit of the University of Santiago de Compostela. All plots were located in pure, even-aged $P$. radiata stands and were measured between two and five times, depending on the plot, during the period 1995-2010. The plots were established throughout the area of distribution of the species in north-western Spain (Fig. 1), a region mainly located in the Atlantic Biogeographical Region (European Environment Agency 2006), where mesophytic deciduous broadleaved and mixed coniferous-broadleaved forests correspond to the natural vegetation (Bohn et al. 2000). The climate of the study region is characterized by mild temperatures (annual average temperature $9-14^{\circ} \mathrm{C}$ ) and a slight water deficit in summer (average annual rainfall 1000-2000 mm; average annual PET 700$850 \mathrm{~mm}$; water deficit 150-40 mm). Sample stands were established on the most representative soils, i.e. those developed on granitic rocks (granites and granitic gneisses) and acid schist. Growth of these forest species is closely related to certain limitations of the soils, such as the moderate depth and the poor nutritional conditions resulting from strong soil acidity.

The selection of the plots aimed to represent the existing range of ages, stand densities and site productivities. The plot size ranged from 625 to $1200 \mathrm{~m}^{2}$, depending on stand density, to include a minimum number of 30 trees per plot. All trees in each sample plot were labelled with a number, and the diameter at breast height ( $\mathrm{dbh}$, at $1.3 \mathrm{~m}$ from the ground) was measured with a calliper to the nearest $0.1 \mathrm{~cm}$. In the first inventory, total height was measured with a Blume Leiss hypsometer to the nearest $0.25 \mathrm{~m}$ in a random sample of 30 trees and in an additional sample including the dominant trees (the proportion of the 100 largest-dbh trees per hectare, depending on plot size). In the remaining inventories, total tree height was measured with a digital hypsometer (Vertex II, Haglöf Sweden) to the nearest $0.1 \mathrm{~m}$ in all trees. Descriptive variables were also recorded for each tree, e.g. whether they were alive or dead. Summary statistics of the main stand variables for each plot inventory are shown in Table 1 .

\subsection{SI and SF dynamic equations}

Growth equations of site-dependent forest variables must have at least the three following properties (Clutter et al. 1983): (i) biological meaning, they must have a coherent inflexion point and an asymptotic value when the projected stand age approximates infinity; (ii) path invariance, the result of projecting first from $t_{0}$ to $t_{1}$, and then from $t_{1}$ to $t_{2}$, must be the same as that of the one-step projection from $t_{0}$ to $t_{2}$; and (iii) simplicity, models that are too complex and include many interactions between individual variables may be affected by correlations between the variables, making them unstable and with a low predictive capacity. Most of these properties can be achieved using dynamic equation derivation techniques known in forestry as the Algebraic Difference Approach (ADA) (Bailey and Clutter 1974) or its Generalization (GADA) (Cieszewski and Bailey 2000).

In this study, after a comparison of different base models and ADA and GADA formulations (see Diéguez-Aranda et al. 2005), we focused our attention on a two site-specific parameter dynamic equation derived with GADA based on the Hossfeld IV model (Hossfeld 1882), which provided the major fitting for both SF and SI curve development (Table 2). In the case of SF, an additional constant of 1.3 was added to the right-hand side of the equation to force the curves to pass through the point $(0,1.3)$. The site-specific local parameters

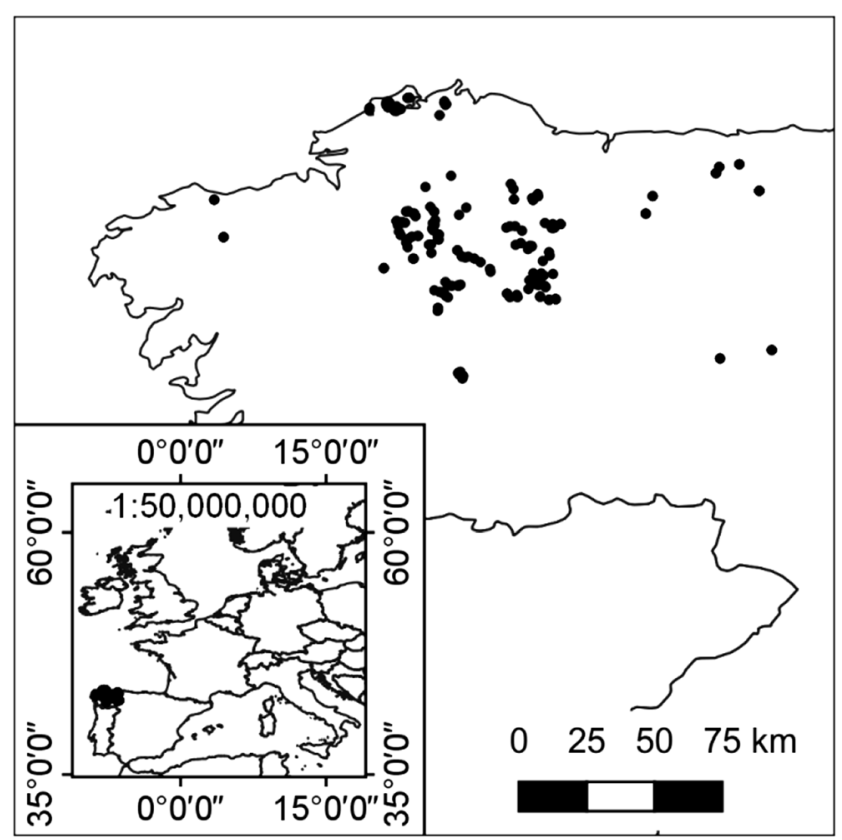

Fig. 1 Location of the plots throughout the study area (north-western Spain) 


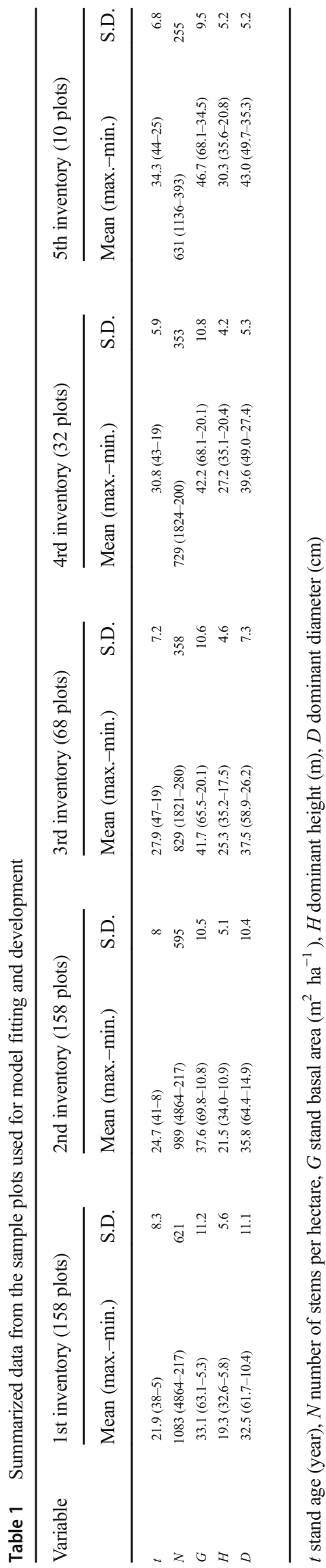

(for each plot) were simultaneously estimated with the global parameters (for all plots) using the dummy variable method described in Cieszewski et al. (2000).

The reference age for predicting SI values was selected as 20 years as Diéguez-Aranda et al. (2005) established for $P$. radiata plantations in north-western Spain. The reference dominant diameter was selected so that it was a reliable predictor of height at other ages (Goelz and Burk 1992). Different base diameters, and their corresponding observed heights, were used to estimate heights at other diameters (both forward and backward) for each plot. The results were compared with the values obtained from plot data, after which the relative error in predictions (RE\%) was calculated using Eq. 1. The proximity to the mean dominant diameter for the studied stands at the age of 20 years was also considered, because it is the $t_{0}$ and therefore, both estimators, SI and SF, could be more comparable.

$\mathrm{RE} \%=\sqrt{\sum_{i=1}^{n}\left(\frac{\left.Y_{i}-\hat{Y}_{i}\right)^{2} /(n-p)}{\bar{Y} 100}\right.}$

where $Y_{\mathrm{i}}, \hat{Y}_{\mathrm{i}}$ and $\bar{Y}$ are the observed, predicted and mean values of the dominant height, respectively, $n$ is the total number of observations and $p$ is the number of model parameters.

We fitted the nonlinear models with the nls function of the R software environment ( $R$ Core Team 2013). Two goodnessof-fit statistics were calculated: the coefficient of determination $\left(R^{2}\right)$, which indicates the proportion of the variance of the dependent variable explained by the model, and the root mean square error (RMSE), which assesses the precision of the estimates. In addition, graphical analysis of the residuals and of the appearance of the fitted curves overlaid on the trajectories of the dominant height of the plots was also conducted.

\subsection{Comparative performance of SI and SF as site quality estimators}

As already mentioned, Vanclay and Henry (1988) outlined the characteristics that an index should possess to be accepted as a measure of site quality. Firstly, in order to assess the consistency of the indices over long periods of time, we analysed similarities in the uncertainties in the prediction of SI and SF. This was carried out by visually comparing the standard deviation of standardized values computed for each plot across different inventories. We standardized the values for each approach from 0 to 1 by using the absolute minimum and maximum values, respectively.

The second criterion of Vanclay and Henry (1988) (SF must be indicative of the site and not influenced by the stand conditions or management history) can also be formulated as by Huang and Titus (1993): the height-diameter relationship of the 
Table 2 Dynamic equations derived from the base model of Hossfeld IV used for fitting SI and SF curves

\begin{tabular}{lllc}
\hline Model & $\begin{array}{l}\text { Site-related } \\
\text { parameters }\end{array}$ & $\begin{array}{l}\text { Dependent } \\
\text { variable }\end{array}$ & Dynamic equation \\
\hline$Y=\frac{a_{1}}{1+a_{2} t^{-a_{3}}}$ & $\begin{array}{l}a_{1}=X \\
a_{2}=b_{2} / X\end{array}$ & SI & $Y=\frac{X_{0}}{1+\frac{b_{2}}{X_{0}} t_{0}^{-b_{3}}}$ \\
& SF & $X_{0}=\frac{1}{2}\left[Y_{0}-b_{1}+\sqrt{Y_{0}{ }^{2}+4 b_{2} Y_{0} t_{0}^{-b_{3}}}\right]$ \\
& & $Y=1.3+\frac{X_{0}}{1+\frac{b_{2}}{X_{0}} t_{0}^{-b_{3}}}$ \\
& & $X_{0}=\frac{1}{2}\left[\left(Y_{0}-1.3\right)+\sqrt{\left(Y_{0}-1.3\right)^{2}-4 b_{2} t_{0}^{-b_{3}}\left(1.3-Y_{0}\right)}\right]$
\end{tabular}

dominant and codominant trees must not be affected by stand density. We assessed this criterion by means of the Pearson correlation coefficient $(r)$ of the predicted SI and SF against Reineke's Stand Density Index (SDI) (Reineke 1933):

$\mathrm{SDI}=N\left(25.4 / d_{g}\right)^{-1.605}$

where $N$ is the stand density (trees ha ${ }^{-1}$ ) and $d_{\mathrm{g}}$ the quadratic mean diameter $(\mathrm{cm})$.

The correlations between both SI and SF, and a direct measure of site quality were determined using the maximum mean annual volume increment (MAI) of each plot as a surrogate for the latter variable. Although other stand variables, such as maximum stand height, stand basal area, stand basal area increment and periodic annual volume increment, have been used as surrogates (e.g. Vanclay and Henry 1988; Vanclay 1994), the maximum MAI is considered the most appropriate direct measure of site quality because it is strongly related to the wood volume that can be obtained in a given site (Skovsgaard and Vanclay 2008). Soil characteristics and climatic factors are, ultimately, the main drivers of the site quality variation (Skovsgaard and Vanclay 2008).

The following sequential steps were carried out for selecting the data for correlation analysis: (i) We predicted MAI for each plot and inventory by using the stand volume equation for $P$. radiata available in Diéguez-Aranda et al. (2009); (ii) we selected the maximum MAI value observed for each plot; and (iii) we compared the current age of the plot for the maximum observed MAI with the Optimal Rotation Age (ORA) (the age of the stand for the potential maximum MAI). The ORA was estimated for each plot by using the dynamic whole-stand growth model developed by CastedoDorado et al. (2007), considering as input stand variables for each plot those corresponding to the inventory with the largest observed MAI. Plots with differences greater than 10 years between the ORA and the current stand age for the maximum observed MAI were disregarded. A total of 78 plots out of 158 were ultimately used for correlation analysis using the Pearson correlation coefficient.
In addition to the desirable characteristics suggested by Vanclay and Henry (1988), SF is usually used as a site quality index under the assumption that the ratio $d_{\mathrm{g}} /$ Hmean (usually referred in the literature as tree taper) decreases as site quality increases (Huang and Titus 1993; Duan et al. 2018). This assumption was assessed computing the Pearson correlation coefficient between tree taper and predicted SF for each plot-inventory combination. The same analysis was carried out for SI for comparison purposes.

\section{Results}

\subsection{SI and SF dynamic equations}

A reduced model of Hossfeld IV with $b_{1}=0$ was used, which coincides with M6 in Wang et al. (2007) and model 11 in Cieszewski (2002). The estimates of the parameters for both GADA-derived dynamic equations were significant at $5 \%$ level (Table 3 ). The $R^{2}$ and RMSE values were 0.988 and $0.634 \mathrm{~m}$ for SI, and 0.986 and $0.687 \mathrm{~m}$ for SF. Visual comparison of the fitted curves overlaid on the trajectories of the observed dominant height (Fig. 2) confirmed the good performance of both models.

In selecting the base diameter, it was found that a diameter of $30 \mathrm{~cm}$ was superior for predicting height at other diameters (Fig. 3), because it presents a good

Table 3 Parameter estimates and goodness-of-fit statistics for SI and SF dynamic equations

\begin{tabular}{lccccc}
\hline Modelled variable & \multicolumn{2}{l}{ Parameter } & $p$ value & $R^{2}$ & RMSE (m) \\
\hline SI & $b_{1}$ & 0 & & 0.988 & 0.634 \\
& $b_{2}$ & 8059 & 0.0001 & & \\
SF & $b_{3}$ & 1.62 & 0.0001 & & \\
& $b_{1}$ & 0 & & 0.986 & 0.687 \\
& $b_{2}$ & 83,199 & 0.0001 & & \\
& $b_{3}$ & 1.61 & 0.0001 & & \\
\hline
\end{tabular}




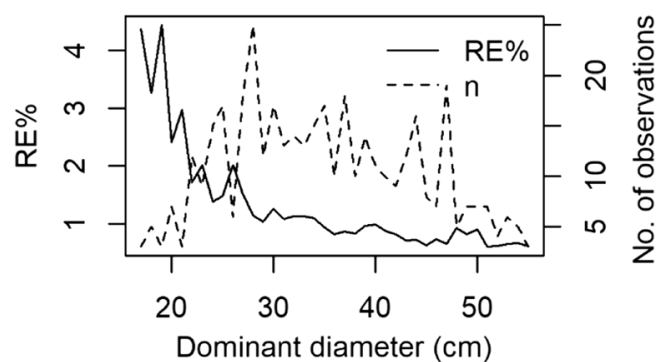

Fig. 2 Relative error (RE\%) in dominant height prediction related to choose of reference dominant diameter

compromise between a low RE\% (about 1\%) and a substantial number of observations. Additionally, this value is quite similar to dominant diameter for the studied stands at the age of 20 years $\left(t_{0}\right)$. Therefore, a reference dominant diameter of $30 \mathrm{~cm}$ was used to obtain the family of SF curves shown in Fig. $2 b$.

\subsection{Comparative performance of SI and SF as site quality estimators}

The standardized values of SI and SF were positively correlated $(r=0.66 ; p<0.0001)$. In addition, the error bars for both variables showed similar uncertainties (Fig. 4). In very few cases, and mainly for extreme values of SI and SF, the variability in SF prediction was larger than that in SI.

Regarding the influence of stand density, as expected, the SDI was not significantly correlated with either SI $(r=0.13$, $p=0.08)$ or SF $(r=0.024, p=0.62 ;$ Fig. 5$)$. This indicates that SF may be a consistent indicator of site quality in $P$. radiata across different management regimes.

The predicted values of both SI and SF were positively and significantly correlated with the maximum observed MAI of the 78 selected plots (Fig. 6). SI was more closely correlated with this surrogate of site quality $(r=0.89)$ than SF $(r=0.70)$.

The ratio $d_{\mathrm{g}} /$ Hmean showed a stronger negative correlation $(r=-0.88 ; p<0.001)$ with SF than with SI $(r=-$ $0.62 ; p<0.001$ ) (Fig. 7). This result could be expected a priori because as SF, tree taper is calculated by an allometric relationship between diameters and height variables.

\section{Discussion}

Although SI has traditionally been considered the reference site quality index for $P$. radiata (Diéguez-Aranda et al. 2005) and for even-aged monocultures in general (Burkhart Harold and Tomé 2012, p. 131), SF has also shown good performance as an estimator of site quality in even-aged $P$. radiata stands. Moreover, SF has the main advantage of not requiring age information, but only dominant height and dominant diameter values, which can be directly derived from field data generally obtained in traditional field inventories. This makes SF suitable for estimating site quality from existing National Forest Inventory (NFI) data in most countries, where stand age is not generally recorded. In addition, considering that estimation of forest potential was included in the 'Forest Principles' for sustainable forest management in the Rio Conference (UNCED 1992), SF could be an operational and inexpensive estimator, being useful not only for designing silvicultural guidelines according to timber yield at stand level (Pretzsch et al. 2008) but also for forest policy decision-making on a large scale, such as REDD+ projects (Pérez-Cruzado et al. 2015). An example of large-scale use of SF is found in MorenoFernández et al. (2018), who observed that countrywide estimations of SF from NFI were consistent with species autoecology.
Fig. 3 SI (a) and SF (b) curves for dominant heights of $11,16,21$ and $26 \mathrm{~m}$ at 20 years and $30 \mathrm{~cm}$, respectively, overlaid on the observed data
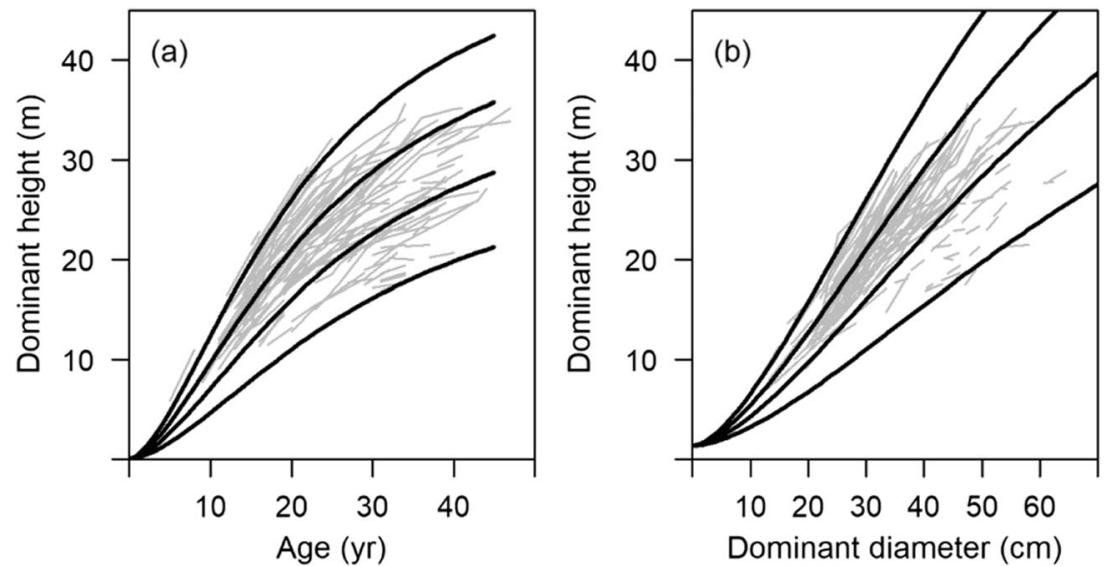


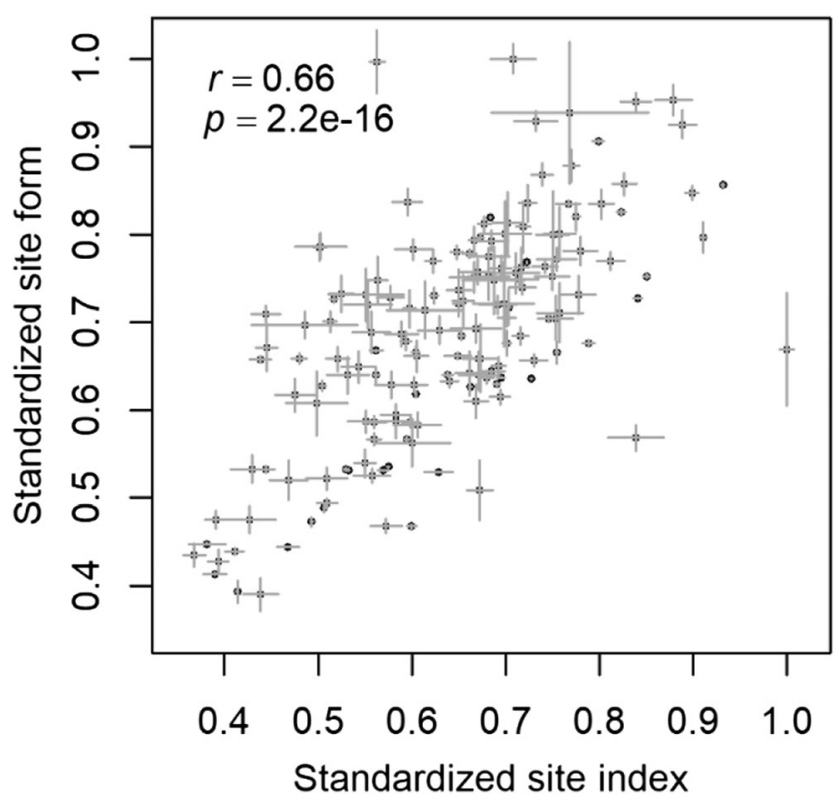

Fig. 4 Relationship between the standardized SI and SF predictions for each plot (dots). Error bars (grey) represent the standard deviations of the predictions

The evolution of dominant height over dominant diameter (SF curves) was modelled with similar accuracy than the evolution of dominant height over time (SI curves) for our case study. The goodness-of-fit statistics obtained for the SF models were superior to those obtained by Beltran et al. (2016) for Nothofagus alpine and Nothofagus obliqua temperate forest, even-aged mature stands in north-western Patagonia (Argentina).

The asymptotic dominant height values for all the SF curves were not achieved within the range of observed dominant diameters. Nevertheless, the dominant height asymptotes for the SI curves shown in Fig. 2a seem realistic (30 to $40 \mathrm{~m}$ ) according to the observed maximum height growth for $P$. radiata in north-western of Spain (Diéguez-Aranda et al. 2005). In both models, higher SI and SF values produced stepper curves, and therefore polymorphism, which is a desirable characteristic of site equations (Cieszewski 2002).

Although SI has proven to be more stable than SF (higher percentage of plots with lower estimation errors), SF also demonstrated satisfactory results. Considering that the projection period used (a maximum of 15 years) was almost half the usual rotation age for the species in north-western of Spain (Castedo-Dorado et al. 2007), it can be assumed that the first criterion suggested by Vanclay and Henry (1988) was also achieved by SF. Moreover, analysis of the standard deviations in SI and SF estimations for each plot showed that the uncertainties associated with both methods were usually similar, which indicates similar uncertainty in both indices when predicting site quality for different stand development stages of the same plot.

The second criterion was fulfilled by both indices (although a weaker correlation with SDI was obtained in the case of SF). This result could be expected, as it is generally accepted that dominant height is not greatly affected by stand density or thinning treatments which do not impact dominant trees (Clutter et al. 1983, p. 65), as is the case of the studied stands.

The correlation of the maximum observed MAI with SI was slightly greater than with SF, although it was high for both indices, highlighting that both estimators are related to productive potential of the site. Similar results were obtained between annual volume increment and SI or SF by Fu et al. (2018) in uneven-aged stands of Mongolian oak (Quercus mongolica) and Korean larch (Larix olgensis).

The assumption that tree taper decreases as site quality increases was fulfilled by both SI and SF. Therefore, the present findings show that this assumption generally holds, with increasing site quality leading to increased dominant height for a given dominant diameter. This assumption is more certain for SF, which was more strongly correlated with tree taper. This negative
Fig. 5 Scatter plots of the predicted SI (a) and SF (b) against stand density index (SDI) for each re-measurement of all the plots. Black line illustrates the linear regression between the two variables. $r$ is the Pearson correlation coefficient, and $p$ is the $p$ value
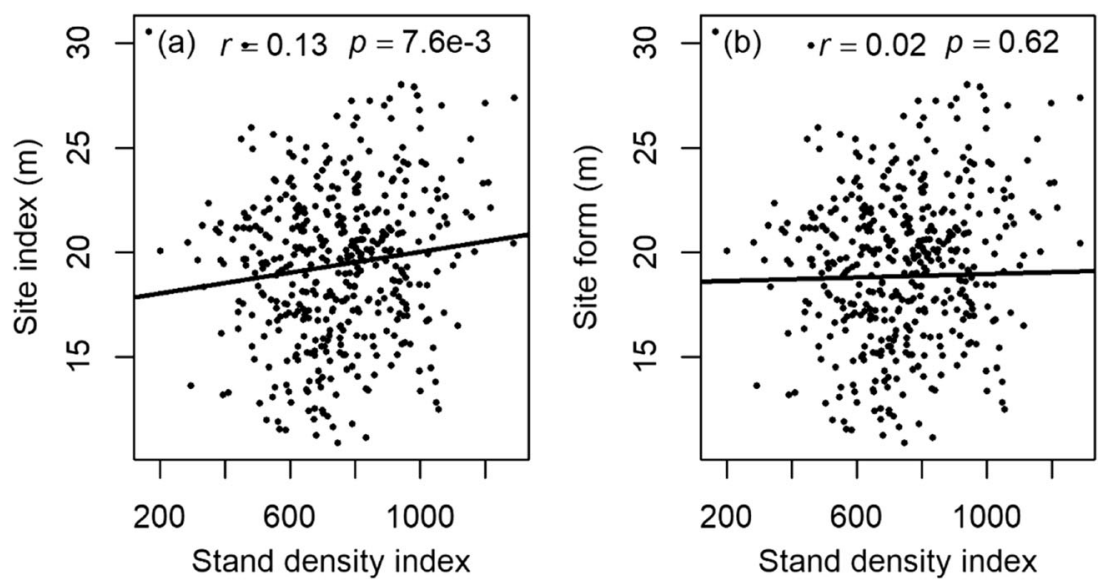
Fig. 6 Scatter plots of MAI $\left(\mathrm{m}^{3}\right.$ year $^{-1}$ ha $\left.^{-1}\right)$ against SI (a) and SF (b). Black line illustrates the linear regression between the two variables. $r$ is the Pearson correlation coefficient, and $p$ is the $p$ value
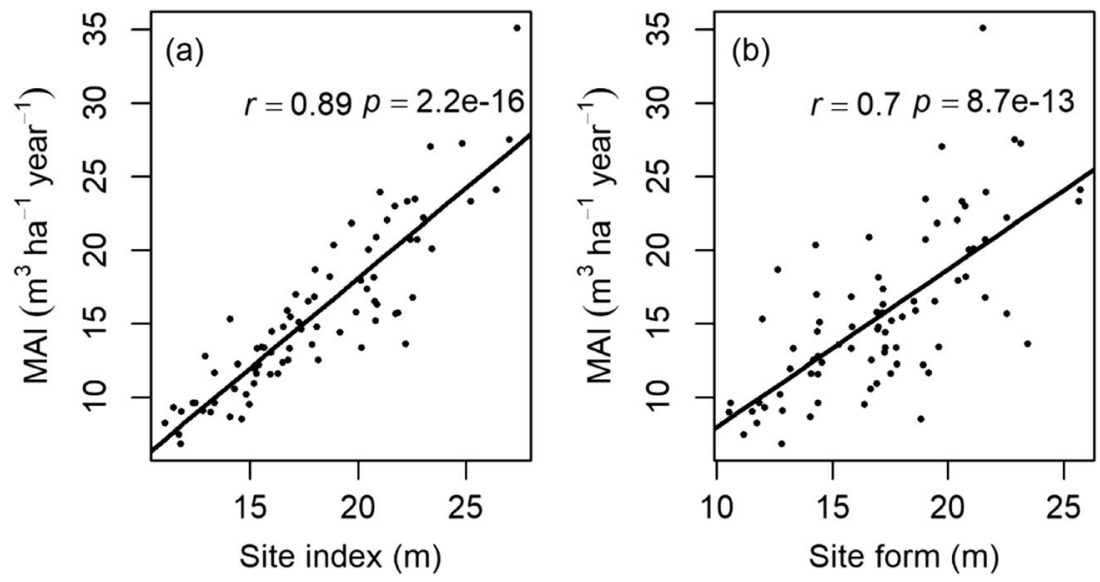

correlation could be expected a priori because for the same reference dominant diameter, higher values of SF represent higher values of dominant heights. It also confirms previous findings for uneven-aged stands (Larson 1963; Fu et al. 2018) but contradicts other findings of no correlation between tree taper and SI (Wang 1998), or a strong positive correlation (Buda and Wang 2006).

SF has scarcely been used over the last decades, and recent studies have been principally concerned with uneven-aged stands (e.g. Adeyemi 2016; Ahmadi et al. 2017; MorenoFernández et al. 2018). Nevertheless, this is significant because there was just one report of its use from 1995 to 2016 (Herrera-Fernández et al. 2004) several papers. The present findings can contribute to demonstrate the usefulness of $\mathrm{SF}$ as a reliable estimator of site quality in pure even-aged stands, which has also been suggested by Beltran et al. (2016). In consequence, the performance of SF observed in this study as indicator of site quality can be the cornerstone for a renewable interest in the use of SF for management of even-aged stands at large scales, where the lack of age information usually leads to more complex methodological solutions (i.e. Arias-Rodil et al.
2015). Further research is needed in order to evaluate the effect of past density management on SF predictions.

\section{Conclusion}

The present study has shown that SF, the expected dominant height for a reference dominant diameter, is potentially a reliable estimator of site quality, performing similarly to SI for even-aged pure stands of $P$. radiata. Unlike SI, SF is not based on stand age and could therefore be used in the absence of this variable or when it is costly to obtain in forest inventories. Furthermore, the possibility of estimating SF from conventional National Forest Inventory data covering large scales makes it an interesting indicator for forest policy decisionmaking, where the scale of the predictions requires lowinput indices. Nevertheless, researching further using data from other species, especially those for which site index modelling has demonstrated a good performance and covering a wide range of management regimes and development stages,
Fig. 7 Scatter plot of tree taper $\left(d_{\mathrm{g}} /\right.$ Hmean $)$ against $\mathrm{SI}(\mathbf{a})$ and $\mathrm{SF}$ (b). Black line illustrates the linear regression between the two variables. $r$ is the Pearson correlation coefficient, and $p$ is the $p$ value
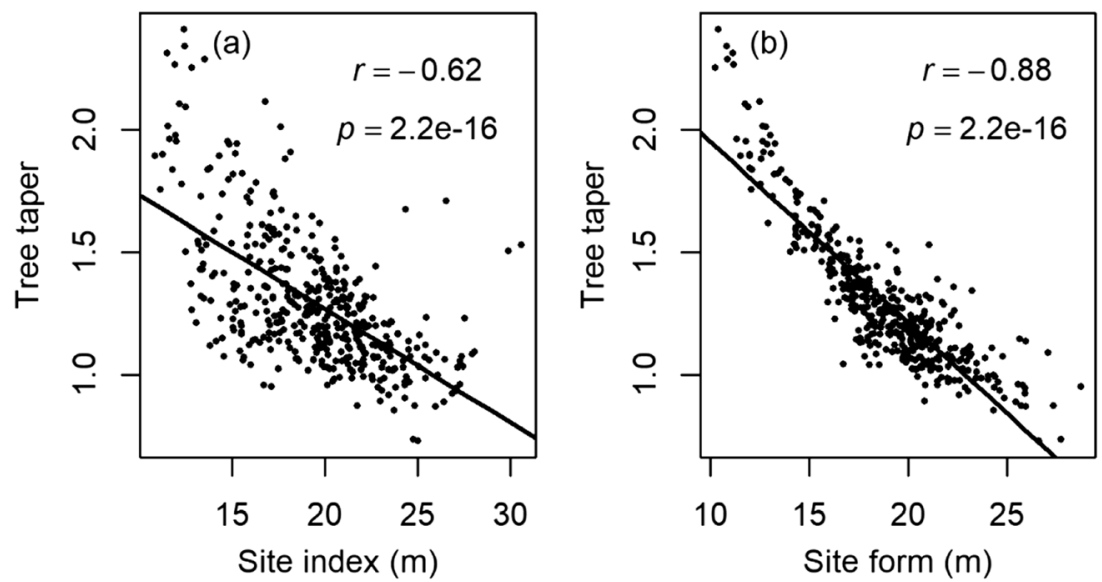
it is advisable to confirm SF as a useful site productivity index for even-aged stands.

Acknowledgements The authors thank Dr. Christine Francis for language revision.

Funding information This study was funded by the Spanish Ministry of Science, Innovation and Universities (AGL2016-76769-C2-2-R). JAMV was funded by Ministry of Education through the FPU program (FPU16/ 03057). CPC was funded by the Spanish Secretariat of State for Research, Development and Innovation through the JdC-I fellowship and by the European Commission thorough the MSCA-EF QUAFORD.

Data availability The datasets generated during and/or analysed during the current study are available from the corresponding author on reasonable request.

\section{Compliance with ethical standards}

Conflicts of interest The authors declare that they have no conflict of interest.

Open Access This article is distributed under the terms of the Creative Commons Attribution 4.0 International License (http:// creativecommons.org/licenses/by/4.0/), which permits unrestricted use, distribution, and reproduction in any medium, provided you give appropriate credit to the original author(s) and the source, provide a link to the Creative Commons license, and indicate if changes were made.

\section{References}

Adeyemi AA (2016) Site quality assessment and allometric models for tree species in the Oban Forest, Nigeria. J Sustain Forest 35:280 298. https://doi.org/10.1080/10549811.2016.1168306

Ahmadi K, Alavi SJ, Kouchaksaraei MT (2017) Constructing site quality curves and productivity assessment for uneven-aged and mixed stands of oriental beech (Fagus oriental Lipsky) in Hyrcanian forest, Iran. For Sci technology 13:41-46. https://doi.org/10.1080/ 21580103.2017.1292959

Arias-Rodil M, Crecente-Campo F, Barrio-Anta M, Diéguez-Aranda U (2015) Evaluation of age-independent methods of estimating site index and predicting height growth: a case study for maritime pine in Asturias (NW Spain). Eur J fort res 134:223-233. https://doi.org/ 10.1007/s10342-014-0845-Z

Bailey RL, Clutter JL (1974) Base-age invariant polymorphic site curves. For Sci 20:155-159. https://doi.org/10.1093/forestscience/20.2.155

Beltran HA, Chauchard L, Velásquez A, Sbrancia R, Pastur GM (2016) BELTRAN, Hernan Attis, et al. diametric site index: an alternative method to estimate site quality in Nothofagus obliqua and N. alpina forests. CERNE 22:345-354. https://doi.org/10.1590/ 01047760201622032207

Bohn U, Gollub G, Hettwer C, Neuhäuslová Z, Raus T, Schlüter H, Weber H, Hennekens S (2000). Map of the natural vegetation of Europe

Buda NJ, Wang JR (2006) Suitability of two methods of evaluating site quality for sugar maple in Central Ontario. For Chron 82:733-744. https://doi.org/10.5558/tfc82733-5

Burkhart Harold E, Tomé M (2012) Modeling Forest trees and stands. Springer, Netherlands
Castedo-Dorado F, Dieguez-Aranda U, Álvarez-González JG (2007) A growth model for Pinus radiata D. Don stands in North-Western Spain. Ann For Sci 64:453-465. https://doi.org/10.1051/forest

Cieszewski CJ (2002). Comparing fixed- and variable-base-age site equations having single versus multiple asymptotes. For Sci 48: 7-23. doi.org/10.1093/forestscience/48.1.7

Cieszewski CJ, Bailey RL (2000) Generalized algebraic difference approach: theory based derivation of dynamic site equations with polymorphism and variable asymptotes. For Sci 46:116-126. https://doi. $\operatorname{org} / 10.1093 /$ forestscience/46.1.116

Cieszewski CJ, Harrison M, Martin SW (2000) Practical methods for estimating non-biased parameters in self-referencing growth and yield models. Dissertation, University of Georgia

Clutter JL, Fortson JC, Pienaar LV, Brister GH, Bailey RL (1983) Timber management: a quantitative approach. In: Timber Management: A Quantitative Approach. John Wiley \& Sons, Inc, New York

Coops N, Waring R, Landsberg J (1998) Assessing forest productivity in Australia and New Zealand using a physiologically-based model driven with averaged monthly weather data and satellite-derived estimates of canopy photosynthetic capacity. For Ecol Manag 104: 113-127. https://doi.org/10.1016/S0378-1127(97)00248-X

Diéguez-Aranda U, Burkhart HE, Rodríguez-Soalleiro R (2005) Modeling dominant height growth of radiata pine (Pinus radiata D. Don) plantations in North-Western Spain. For Ecol Manag 215:271284. https://doi.org/10.1016/j.foreco.2005.05.015

Diéguez-Aranda U, Rojo Alboreca A, Castedo-Dorado F, Álvarez González JG, Barrio-Anta M, Crecente-Campo F, González González JM, Pérez-Cruzado C, Rodríguez Soalleiro R, LópezSánchez CA, Balboa-Murias MA, Gorgoso Varela JJ, Sánchez Rodríguez F (2009) Herramientas selvícolas para la gestión forestal sostenible en Galicia. Consellería do Medio Rural, Xunta de Galicia, Lugo

Duan G, Gao Z, Wang Q et al (2018) Comparison of different heightdiameter Modelling techniques for prediction of site productivity in natural uneven-aged pure stands. Forests 9:63. https://doi.org/10. 3390/f9020063

European Environment Agency (2006) Progress towards halting the loss of biodiversity by 2010 (Report No. 5/2006). Retrieved from: https://www.eea.europa.eu/publications/eea_report_2006_5

Franklin J, Perry D, Schowalter T, Harmon M, McKee A, Spies T (1989) Importance of ecological diversity in maintaining long-term site productivity. In: Perry D, Meurisse R, Thomas B, miller R, Boyle J, means J, Perry C, powers R (Eds.) timber press, Oregon, pp-82-97

Fu L, Lei X, Sharma RP, Li H, Zhu G, Hong L, You L, Duan G, Guo H, Lei Y, Li Y, Tang S (2018) Comparing height-age and heightdiameter modelling approaches for estimating site productivity of natural uneven-aged forests. Forestry 91:419-433. https://doi.org/ 10.1093/forestry/cpx049

Goelz JCG, Burk TE (1992) Development of a well-behaved site index equation: jack pine in north Central Ontario can. J For Res 22:776 784

Herrera-Fernández B, Campos JJ, Kleinn C (2004) Site productivity estimation using height-diameter relationships in Costa Rican secondary forests. Invest Agrar: Sist Recur For 13:295-303

Hossfeld JW (1882) Mathematik für Forstmänner, Ökonomen und Cameralisten, Gotha

Huang S, Titus SJ (1993) An index of site productivity for uneven-aged or mixed-species stands. Can J For Res 23:558-562. https://doi.org/ $10.1139 /$ x93-074

Lamson NI (1987) Estimating northern red oak site-index class from total height and diameter of dominant and codominant trees in central Appalachian hardwood stands. USDA For Serv Northeast For Exp Stn

Larson PR (1963) Stem form development of Forest trees. For Sci 9:142. https://doi.org/10.1093/forestscience/9.s2.a0001 
Larson AJ, Lutz JA, Gersonde RF, Franklin JF, Hietpas FF (2008) Potential site productivity influences the rate of forest structural development. Ecol Appl 18:899-910. https://doi.org/10.1890/071191.1

McLintock TF, Darby CA (1957). A proposed site index for red spruce in the northeast. USDA Forest Service Northeastern Forest Experiment Station

Meyer HA (1940) A mathematical expression for height curves. J For 38 : 415-420. https://doi.org/10.1093/jof/38.5.415

Moreno-Fernández D, Álvarez-González JG, Rodríguez-Soalleiro R, Pasalodos-Tato M, Ceñellas I, Montes F, Díaz-Varela E, SánchezGonzález M, Crecente-Campo F, Álvarez-Álvarez P, Barrio-Anta M, Pérez-Cruzado C (2018) National-scale assessment of forest site productivity in Spain. For Ecol Manag 417:197-207. https://doi.org/ 10.1016/J.FORECO.2018.03.016

Nicholas NS, Zedaker SM (1992) Expected stand behavior: site quality estimation for southern Appalachian red spruce. For Ecol Manag 47: 39-50. https://doi.org/10.1016/0378-1127(92)90264-A

Peng C (2000) Growth and yield models for uneven-aged stands: past, present and future. For Ecol Manag 132:259-279. https://doi.org/10. 1016/S0378-1127(99)00229-7

Pérez-Cruzado C, Fehrmann L, Magdon P et al (2015) On the site-level suitability of biomass models. Environ Model Softw 73:14-26. https://doi.org/10.1016/J.ENVSOFT.2015.07.019

Pretzsch H, Grote R, Reineking B, Rötzer TH, Seifert ST (2008) Models for forest ecosystem management: a European perspective. Ann Bot 101:1065-1087. https://doi.org/10.1093/aob/mcm246

R Core Team (2013) R: a language and environment for statistical computing. R Foundation for Statistical Computing, Vienna

Reineke L (1933) Perfecting a stand-density index for even-aged forests. J Agri Res 47:627-638

Reinhardt ED (1982) Influence of site quality on the height-diameter relationship of western larch. University of Montana, Dissertation

Reinhardt ED (1983) Using height/diameter curves to estimate site index in old-growth western larch stands. University of Montana, Dissertation

Skovsgaard JP, Vanclay JK (2008) Forest site productivity: a review of the evolution of dendrometric concepts for even-aged stands. Forestry 81:13-31. https://doi.org/10.1093/forestry/cpm041

Stout BB, Shumway DL (1982) Site quality estimation using height and diameter. For Sci 28:639-645
Tomppo E, Schadauer K, McRoberts RE, Gschwantner T, Gabler K, Ståhl G (2010) National Forest Inventories. Springer, Netherlands. https://doi.org/10.1007/978-90-481-3233-1

Trorey LG (1932) A mathematical method for the construction of diameter height curves based on site. For Chron 8:121-132. https://doi. org $/ 10.5558 / \mathrm{tfc} 8121-2$

UNCED (1992) Forest principles: non-legally binding authoritative statement of principles for a global consensus on the management, conservation and sustainable development of all types of forests. In: A/CONF.151/26 (Vol. III)

Vanclay JK (1983) Techniques for modelling timber yield from indigenous forests with special reference to Queenslan. University of Oxford, Dissertation

Vanclay JK (1992) Assessing site productivity in tropical moist forests: a review. For Ecol Manag 54:257-287. https://doi.org/10.1016/03781127(92)90017-4

Vanclay JK (1994) Modelling forest growth and yield: applications to mixed tropical forests. CAB International, Wallingford

Vanclay JK (1995) Growth models for tropical forests: a synthesis of models and methods - synthesis. For Sci 41:7-42

Vanclay JK, Henry NB (1988) Assessing site productivity of indigenous cypress pine forest in southern Queensland. Commonw For Rev 67: $53-64$

Wang GG (1998) Is height of dominant trees at a reference diameter an adequate measure of site quality? For Ecol Manag 112:49-54. https://doi.org/10.1016/S0378-1127(98)00315-6

Wang M, Borders B, Zhao D (2007) Parameter estimation of base-age invariant site index models: which data structure to use? For Sci 53: 541-551. https://doi.org/10.1093/forestscience/53.5.541

Wei X, Kimmins JP, Zhou G (2003) Disturbances and the sustainability of long-term site productivity in lodgepole pine forests in the central interior of British Columbia - an ecosystem modeling approach. Ecol Model 164:239-256. https://doi.org/10.1016/S0304-3800(03) 00062-0

Weiskittel AR, Hann DW, Kershaw JA, Vanclay JK (2011) Forest growth and yield modeling. Wiley-Blackwell, Chichester

Xunta de Galicia. Consellería do Medio Rural (2015) $1^{\mathrm{a}}$ Revisión del Plan Forestal de Galicia

Publisher's note Springer Nature remains neutral with regard to jurisdictional claims in published maps and institutional affiliations. 